\title{
PANORAMIC OF PALEOHABITATS OF PLIOCENE SAHABI FORMATION AND RECENT AS-SAHABI AREA, NORTHERN LIBYA
}

\author{
Ahmed M. Muftah \\ Department of Earth Science, Faculty of Science, University of Benghazi, Benghazi, Libya \\ E-mail: ahmed59muftah@gmail.com \\ Received: 31 August 2019; accepted: 15 October 2019
}

\begin{abstract}
As-Sahabi area is located to the south of Ajdabiyah city in Sirt Basin, Libya. This area considered as a spectacular open Museum of vertebrate remains (i.e. teeth, bones, skulls and skeletons) of mammals, reptiles, aves and fish. This paper presents the methods used during the excavation and lists most of the documented taxa and finally compare these paleo-habitats with the corresponding present-day habitat of As-Sahabi. The As-Sahabi fossils played important role in delineating the paleohabitats and in understanding the migration routes as well as in tracing their evolutionary trends. These remains are preserved in continental deposits (mainly sands and clays) since 5 million years ago. Six paleo-habitats have been suggested "Salt neritic water, Eo-Sahabi River, Riverine forest and river edge, Water's edge and Eo-Sahabi estuary habitats, Savana habitat, and Arid Desert-like habitat. As-Sahabi vertebrates (e.g. crocodiles, hippos, hyena, etc..) are considered to be the ancestral taxa of the descendant vertebrates exist today in other parts of the world. However, some are found to be indigenous taxa due to migration failure such as the gigantic size, Mastodon (Stegotetrabeledon lybicus) and shovel-tusker Proposcidean (Amebelodon cyrenaicus) or medium-sized with short-legged Anthracothere (Libycosaurus petrocchii).

Keywords: As-Sahabi; Vertebrates; Proposcidean; Continental; Libya
\end{abstract}

\section{INTRODUCTION}

The well-known Neogene paleontological site in Libya, As Sahabi (Fig. 1) has attracted not only paleontologists for its open natural museum of Neogene vertebrates, but also tourists for its fascinating scenery and impressive desert landscape panorama. During the 1920's, Italian soldiers noted by accident the presence of mammal fossil bones in the vicinity of the Qasr as Sahabi, a nowruined fort dating from Roman times, located at the southern part of the present paleontological site. In the early 1930's, the famed Italian geologist and paleontologist Ardito Desio, with Professor G. D' Erasmo from Naples and geologist G. Stefanini from the University of Pisa, conducted the first geological and paleontological investigation in the As Sahabi area (Petrocchi, 1934). Carlo Petrocchi, 
a young paleontologist recruited in the 1935 by Desio to study As Sahabi, would become involved for decades in As Sahabi (and Libya), and make discoveries that rendered As Sahabi the most famous Libyan fossil site. Among his first finds (via excavations also), were the skull of the four-tusked elephantid Stegotetrabelodon syrticus and the skull and the in-situ skeleton of a cetacean, a whale (Petrocchi 1934, 1936 and 1941). For more on the discovery of the As Sahabi site, see Rook (2008); for a general presentation of the paleontological site, see Boaz (2008).

The as Sahabi area is located in the northeastern part of Sirt Basin, covering an area of about $375 \mathrm{~km}^{2}$ (Fig. 1). It is bounded by longitudes $20^{\circ} 48^{\prime} 08^{\prime \prime}$ to $20^{\circ} 54^{\prime} 45^{\prime \prime} \mathrm{E}$ and latitudes $30^{\circ} 10^{\prime} 58^{\prime \prime}$ to $30^{\circ} 17^{\prime} 36^{\prime \prime} \mathrm{N}$, within a tectonic province called the Ajdabiyah Trough. The productive samples in terms of vertebrates came from scattered exposures aligned in a $\mathrm{N} 30^{\circ} \mathrm{E}$-trending manner and bounded by the Sabkhat al Qunayyin from the west (Fig. 1). However, the western part of the As Sahabi area is called the Sabkhat Al Qunayyin (Fig. 1).

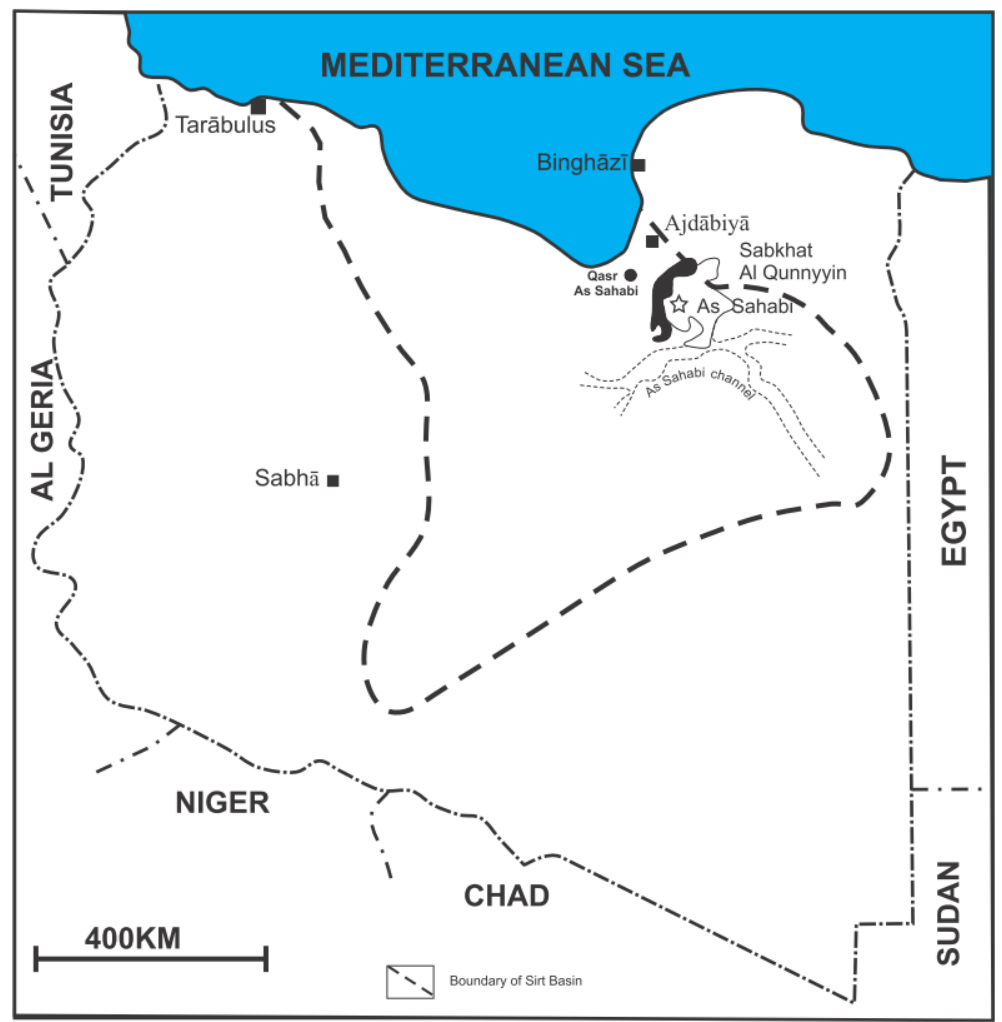

Fig. 1: Index map shows the location of As Sahabi (modified after Muftah, 2013)

\section{MATERIALS AND METHODS}

\section{The Field Work}

The visited stratigraphic outcrops in As Sahabi area for this study consist of two profiles named P10 and P28 (Fig. 2). P10 (Jabal Shagig): Coordinates: Latitudes (30¹'12.58" N) and Longitudes 
( $\left.20^{\circ} 49^{\prime} 24.14^{\prime \prime} \mathrm{E}\right)$. The measured thickness of this profile is 46 meters, represented by all members of Sahabi Formation (Fig. 2). P28 (Elephant hill): Coordinates: Latitudes (30'13'56.69" N) and Longitudes $\left(20^{\circ} 51^{\prime} 26.71^{\prime \prime} \mathrm{E}\right)$. The measured thickness of this profile is $22 \mathrm{~m}$. This section represents by four members of Sahabi Formation, from bottom to top U1 member, UD member, and V member. At this locality a possible complete skeleton of the Mastodon Stegotetrabelodon is buried, from which the name of the hill was derived. An amazing petrified forest is situated in front of this hill (Fig. 2).

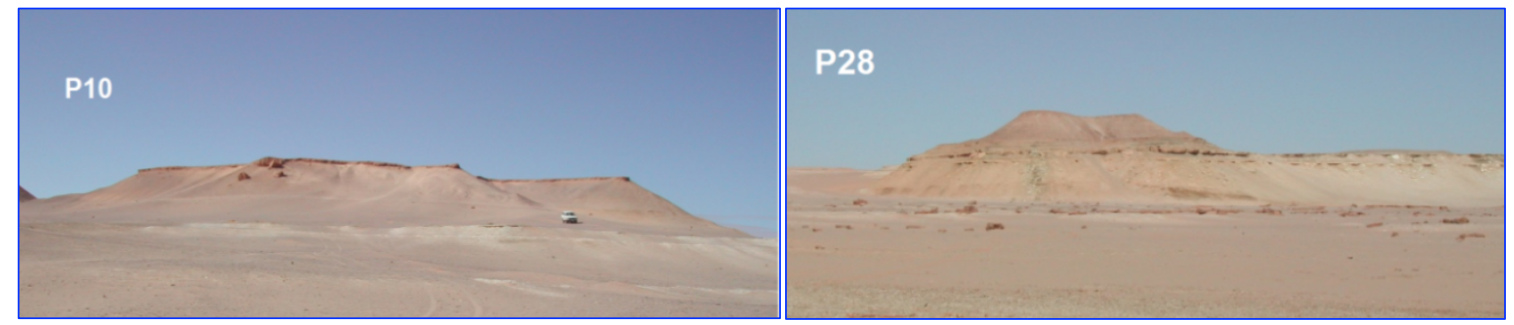

Fig. 2: Jabal Shagig (P10); and Elephant hill (P28)

\section{Excavation Proceedures}

1- Sediments (sands) are removed from around the specimen (Fig. 3A) using painting brush with intensive care, because the" skeleton" is very fragile and will be collapsed easly if subjected to very little force (Fig. 3B).

2- when most of the skeleton is exposed (Fig. 3C) the surface covered with thin Paraloid - B72 or any alternative glue and left this cover for many hours (up to 24 hours) to infiltrate and fill the bone tissue (pores) to hardening the skeleton.

3- The glued skeleton is coated with Aluminium foil and covered with wet cloth. All exposed skeleton coated with Gypsum amalgom and left this for 24 hours to solidify (Fig. 3D).

4- The coated and solidified skeleton is turned upside down (Fig. 3E) with care, then the specimen transported to the Laboratory. The gypsum cover is removed in the laboratory to undergoes the required measurments and identifications by the concerned specialists. 


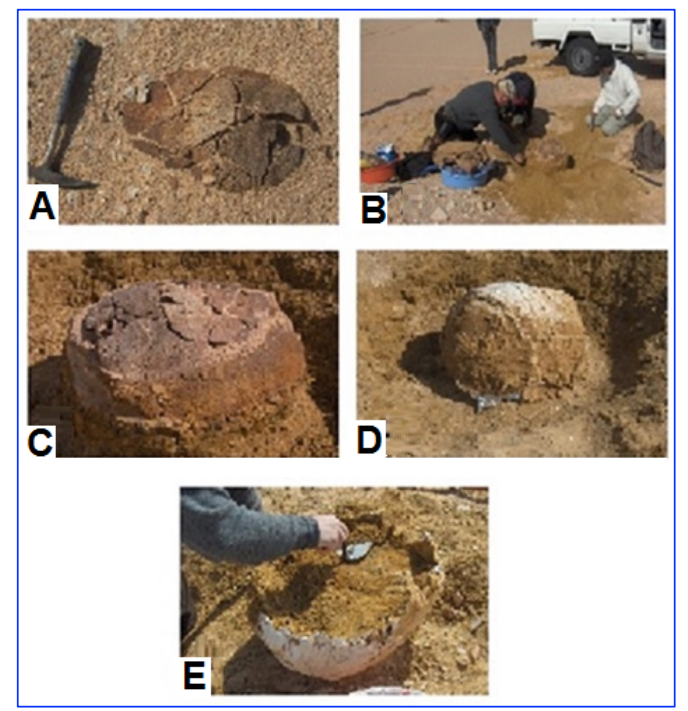

Fig. 3: The excavation steps of Chelonia from AS Sahabi area near the petrified forest at P28

\section{RESULTS AND DISCUSSION}

\section{Geological Settings \\ Stratigraphy}

The As Sahabi area was mapped by De Heinzelin and El-Arnautil (1983\&1987); Muftah et al. (2008); Muftah (2013). Recently, El-Shawaihdi et al. (2014), El-Shawaihdi et al. (2016) amended the lithostratigraphic nomenclatures of the As Sahabi area based on stable isotopes dating of few samples to modify formation " $\mathrm{M}$ " and regional correlation to introduced new "lower member" and "upper member" of Sahabi Formation, Qarrat Waddah Formation and Z Formation, the latest version (Fig. 4) the composite columnar section having adopted four superimposed formations composing the substratum:

1- M Formation: Semiconsolidated bioclasts exposed in floor of the Sebkhat, totally or partially decalcified and gypsified. Erosional relief of shallow reefs "MR" with corals, echinoids, pelecypods and gastropods (De Heinzelin and El-Arnauti, 1987) (Fig. 4).

2- Sahabi Formation: It can be subdivided into two members: i) the lower member $(\approx$ De Heinzelin and El-Arnauti's P member and lowermost part of T member) characterized by semi-consolidated sandy, gypsiferous, and dolomitic limestone. Presence of a large network of fractures ( $\sim 5 \mathrm{~m}$ deep) filled with selenitic gypsum is also a characteristic feature. ii) the upper member $(\approx$ De Heinzelin and El- Arnauti's T, U1, UD, and U2 members of Sahabi Formation) and uppermost part of T member) characterized by Sand with abundant marine fauna in places. Often bioturbated, and containing fish teeth and sirenian skeletons with land mammals. Followed by sands with clay lenses and clay balls incorporating well preserved bones. A transgressive bar, followed by interbedding of sand, clay and 
dolomitic crusts generally bounded between two dolomite beds, the lower one is highly bioturbated (Fig. 4).

3- Qarat Weddah Formation ( $\approx$ De Heinzelin and El- Arnauti's V member): Composes mainly of medium-coarse sands and sandy clays with lenses of dolomite and gypsum crystals (Fig. 4).

4- Z Formation ( $\approx$ De Heinzelin and El- Arnauti's Z member): Very complex fossil soil capping the Sahabi Formation (Fig. 4).

\section{Paleontology Flora}

The Sahabi fossil flora is largely African in nature, as judged by comparative anatomy of the collected fossil wood with the living African species (Dechamps, 1987a; 1987b; Dechamps \& Maes, 1987). These include Acacia mellifera, A. nilotica, A. tortilus, Ekebergia rueppeliana, Sterculia setigera, Adenia gummifera, Cryptosepalum pseudotaxus, Hyphaene thebaica, and Phoenix dactylifera. Evidence of fossil diatoms undigested within coprolites is also recorded from the Sahabi Formation (Burckle, 1982).

\section{Paleontology Fauna}

A large number of mammalian and other vertebrate remains (more than 5000 specimens), have been so far collected and identified from the Sahabi Formation (lower member in the As Sahabi area, with De Heinzelin and El- Arnauti's member "U1" the most prolific in terms of mammalian, reptilian and avian remains. The most common mammalian representatives in the Sahabi Formation after Boaz et al., (2008) are shown on Table (1). Presence of the vertebrate trace fossils (Coprolites) is also common characteristic in the investigated area, which give a clue to the behavior of these organisms (Fig. 5).

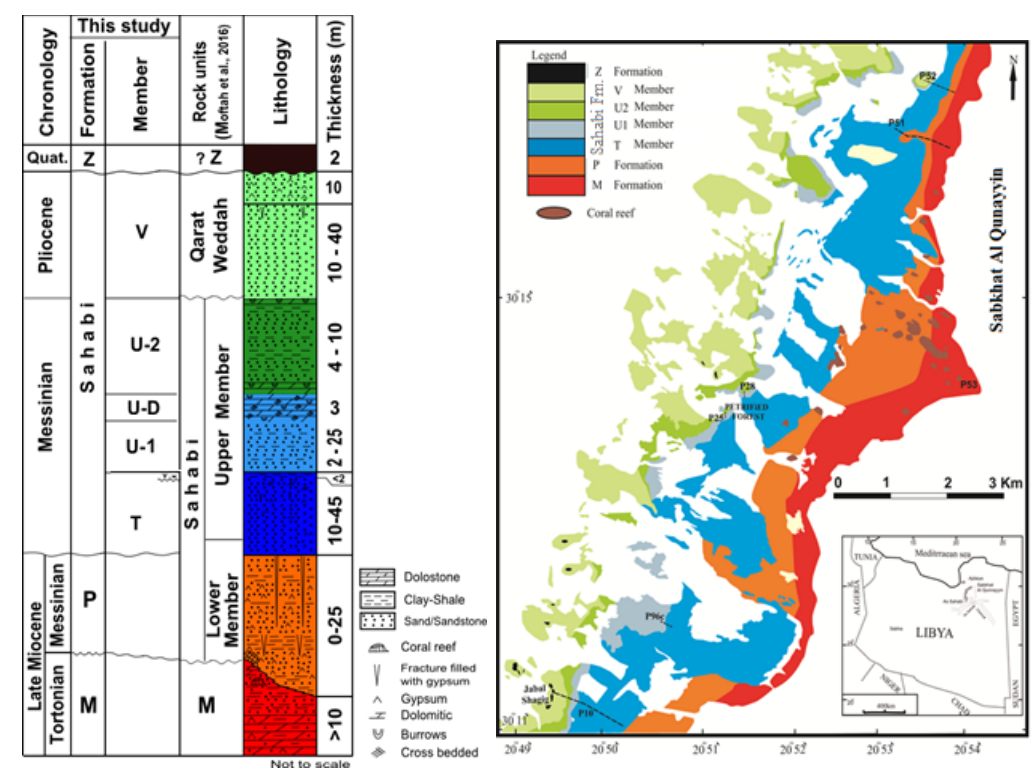

Fig. 4: Geological map and composite stratigraphic column of As Sahabi area shows the studied profiles (Modified after De Heinzelin and El-Arnauti, 1987) 
Table 1: Some of the documented Mammalian faunas from Sahabi Formation (As Sahabi) (after Boaz et al., 2008)

\begin{tabular}{|c|c|c|c|}
\hline Order & Family & Genus & Species \\
\hline Carnivora & $\begin{array}{l}\text { Felidae } \\
\text { Ursidae } \\
\text { Viverridae } \\
\text { Hyaenidae }\end{array}$ & $\begin{array}{l}\text { Machairodus } \\
\text { Indarctos } \\
\text { Viverra } \\
\text { Percrocuta } \\
\text { Hyaenicitherium } \\
\text { Euryboas } \\
\text { gen. indet }\end{array}$ & $\begin{array}{l}\text { sp. } \\
\text { atticus } \\
\text { sp. } \\
\text { senyureki } \\
\text { sp. } \\
\text { sp. } \\
\text { sp. indet }\end{array}$ \\
\hline Proboscidea & $\begin{array}{l}\text { Gomphotheriidae } \\
\text { Elphantidae }\end{array}$ & $\begin{array}{l}\text { Ambelodon } \\
\text { Anacus } \\
\text { Stegotetrabeledon }\end{array}$ & $\begin{array}{l}\text { cyrenaicus } \\
\text { petrocchi } \\
\text { syrticus }\end{array}$ \\
\hline Perissodactyla & $\begin{array}{l}\text { Rhinocetotidae } \\
\text { Equidae }\end{array}$ & $\begin{array}{l}\text { Diceros } \\
\text { "Cremophipparrion } \\
\text { ?Cremohipparion } \\
\text { "Hipparion"(Sivalhippus) }\end{array}$ & $\begin{array}{l}\text { neumayni } \\
\text { aff. matthewi } \\
\text { nikosi } \\
\text { sp. }\end{array}$ \\
\hline Artiodactyla & $\begin{array}{l}\text { Suidae } \\
\text { Hippoptamidae } \\
\text { Anthracotheriidae } \\
\text { Giraffidae } \\
\text { Bovidae }\end{array}$ & $\begin{array}{l}\text { Nyanzachoerus } \\
\text { Nyanzachoerus } \\
\text { Hexaprotodon } \\
\text { Libycosurus } \\
\text { Samotherium } \\
\text { Gazella } \\
\text { Leptobos } \\
\text { Tragoportax } \\
\text { Kobus } \\
\text { ?Hippotragus } \\
\text { cf. Damalacra } \\
\text { Raphicerus } \\
\text { Prostrepsiceros }\end{array}$ & $\begin{array}{l}\text { syrticus } \\
\text { cf. deuauxi } \\
\text { sahabiensis } \\
\text { petrocchii } \\
\text { sp. } \\
\text { sp. } \\
\text { syrticus } \\
\text { cyrenaicus } \\
\text { darti } \\
\text { sp. } \\
\text { sp. } \\
\text { sp. } \\
\text { hibycus }\end{array}$ \\
\hline Cetacea & $\begin{array}{l}\text { Delphinidae } \\
\text { Platanistidae }\end{array}$ & $\begin{array}{l}\text { cf. Lagenorhynchus } \\
\text { gen. indet }\end{array}$ & $\begin{array}{l}s p . \\
s p . \text { indet }\end{array}$ \\
\hline Sirenia & Dugongidae & Metaxytherium & serresii \\
\hline Insectivora & Soricidae & gen. indet. & sp. indet \\
\hline Rodentia & $\begin{array}{l}\text { Cricetidae } \\
\text { Muridae } \\
\text { Ctenodactylidae } \\
\text { Sciuridae }\end{array}$ & $\begin{array}{l}\text { Abudhabia } \\
\text { Myocricetodon } \\
\text { Myocricetodon } \\
\text { Progonomys } \\
\text { Sayimys } \\
\text { cf. Atlantoxerus }\end{array}$ & $\begin{array}{l}\text { yardangi } \\
s p . A \\
s p . B \\
s p . \\
\text { sp. } \\
\text { getulus }\end{array}$ \\
\hline Primates & Cercopithecidae & $\begin{array}{l}\text { Macaca } \\
\text { cf. Libypithecus }\end{array}$ & $\begin{array}{l}\text { sp. } \\
\text { sp. }\end{array}$ \\
\hline
\end{tabular}

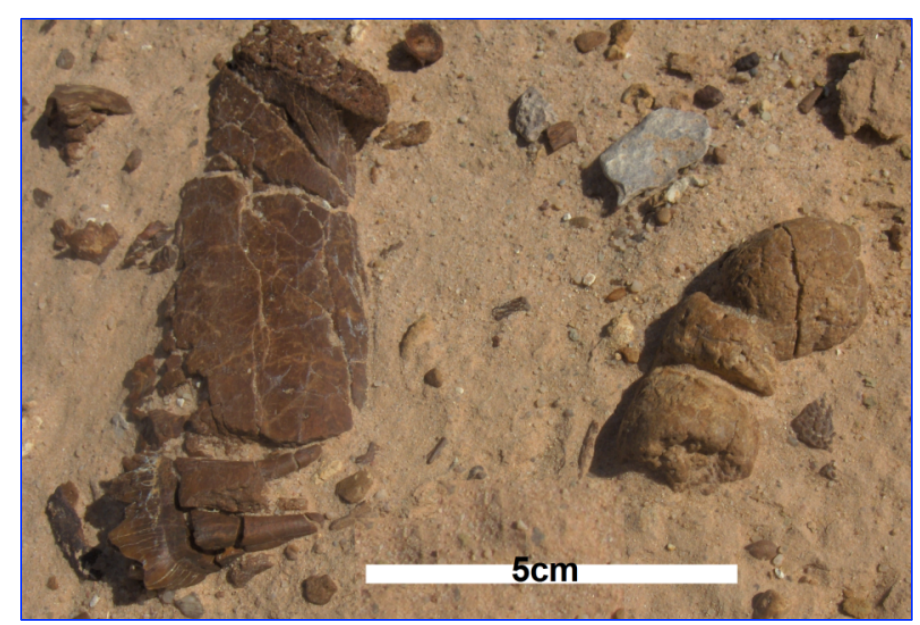

Fig. 5: Close view shows jaw of a mammal and a coprolite (fossillized feces) from the As

\section{Sahabi Eo-Channel}

Sahabi araea, Libya

Carmignani et al., (2009) suggested from remote sensing data that the "Sahabi Channels" of Barr and Walker (1973), which extended by Nicolai (2008) into the Mediterranean Basin by the use of seismic data, represented a late Miocene incursion of the Nile River into Libya. Such a model requires migrate of the Nile from its basin and flow uphill over the higher relief Western Desert to enter the Ajdabya Trough and eventual entry into the Gulf of Sirt. The model is not supported by data on Miocene paleorelief of western Egypt that would make such a hypothesis plausible, and recent remote sensing data 
(Paillou et al. 2009) support a separate Libyan hydrographic drainage pattern distinct from the Nile. Moreover, Muftah et al., (2013) suggested that the source of the river was Chad mega Lake (Fig. 6) based on geochemical analysis of the clay sediments of Member U1 of Sahabi Formation, where, their geochemical composition might also be explained by an origin from Precambrian outcrops within the Ethiopian highlands near Lake Tana in the catchment area of the Blue Nile, paleontological evidence (Table. 1) renders this is an unlikely hypothesis (Muftah et al., 2013).

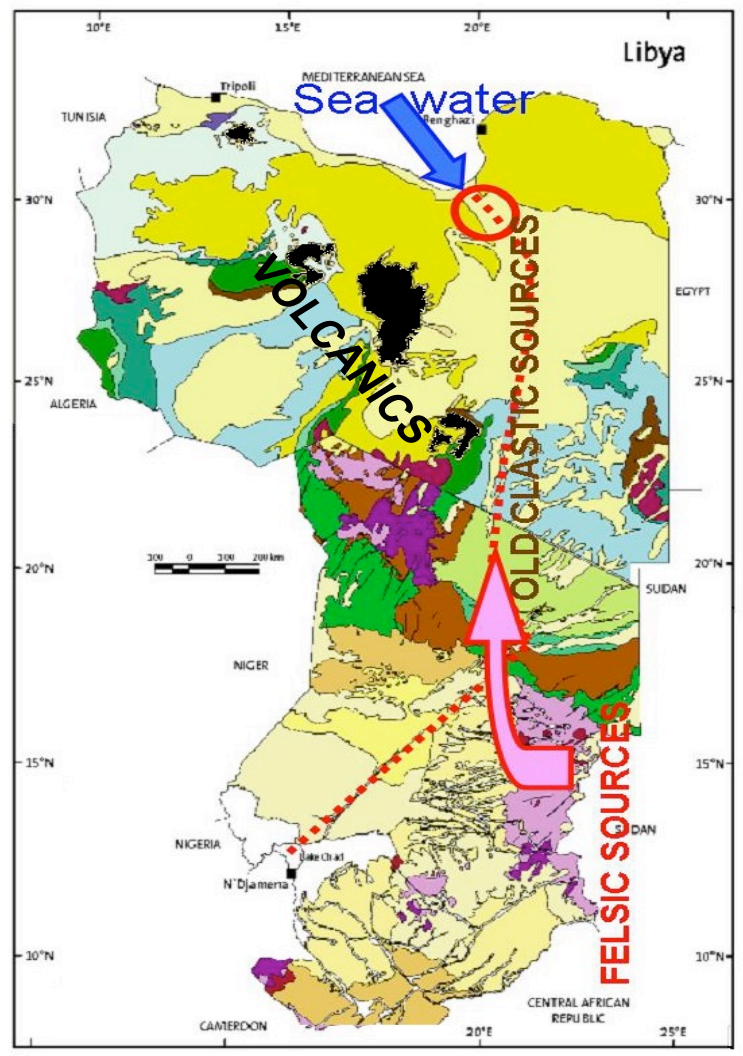

Fig. 6: Map shows the proposed origin of sediments of the vertebrate bearing member U1 of Sahabi Formation from Chad paleolake (Muftah et al., 2013)

\section{The Palelo-Habitats}

Six main paleo-habitats have been interpreated by Boaz (2009) during Pliocene time (i.e. more than 5 million years ago) from the excavated fossil vertebrates (Fig. 7). The main controller event for all these are the Eo-Sahabi river which was discovered by Barr and Walker (1973). These hypothesied paleo-habitats are:

1. Salt water paleo-habita: It was suggested due to the presence of the sea crocodile (Crocodylus checchiai) sea turtles (Trionyx triungus); sea cow (Metaxytherium serresii); great white shark (Carcharodon megalodon); in addition to the birds such as Geese (Anatidarum sp.). Meanwhile, 
the flora are represented by Doum palm tree (Hyphaena tehbaica); Date palm tree (Phoenix sp.); and Fig tree (Myrianthoxylon sp.) (Fig. 7A) Boaz (2009).

2. Eo-Sahabi River paleo-habitat: It was suggested due to the presence of the long-snouted crocodile (Euthecodon sp.); River dolphine (Iniidae sp.); Bottle-noused dolphine (Lagenorynchus sp.); (Platanistadea), reverine fish, Nile Catfish (Clarias sp.); Squeaker catfish (Synodontis sp.); Crucifix catfish, Widehead cat fish (Clarotes sp.); Perch (Percoidea sp.); Nile perch (Lates nilotica); Bichir (Polypterus sp.) and Sea bream (Sparidae sp.) (Table 1 and Fig. 7B) Boaz (2009).

3. Riverine forest and river edge paleo-habitats: They were suggested due to the presence of the Sixfore-toothed hippopotamus (Hexaprotodon sahabiensis); the Four-tusked mastodon- elephant (Stegotetrabeledon syrticus); the African bear (Agriotherium africanum); Macaque-like cercopithecine monkey (Parapapio sp.) and Colobus monkey (Colobinae indet.); in addition to the birds such as Darter (Anhinga sp.) and Eagle (Accipitridae sp.). Meanwhile, however, the flora are in form of Sausage tree (Kigelia africana); Cape ash tree (Ekebergia acpensis); Acacia tree (Acacia nilotica); Bush willow tree (Combretum sp.) and Doum palm trees (Phoeneix sp.) as largely learned from the the fossil wood (Fig. 7C) Boaz (2009).

4. Water's edge and Eo- Sahabi estuary Paleo-habitats: They were suggested due to the presence of the Anthracothere (Libycosaurus petrocchii); the shovel-tusker proboscidean (Amebeledon cyrenaicus) and the predator Sabertooth (Amphimachairodus aff. kabir) and the harbor seal (Monachus sp.). Meanwhile, the flora are in form of Mangroove tree (Rhizophora sp.); tropical chestnut tree (Sterculina setigera); Acacia tree (Acacia tortilis); Bush willow tree (Combretum sp.); Susage tree (Kigelia africana) and Date palm trees (Phoeneix sp.) as largely learned from the the fossil wood (Fig. 7D) Boaz (2009).

5. Savana Paleo-habitat: It was suggested due to the diverse mammalian community consisting of the Hyena (Percrocuta sp. \& Chasmaporthetes sp.); the wild hog (Nyanzachoerus syrticus); the bovida antilopes (Hippotragus libycus, Kobus subdolus, Gazella sp., Dytikodorcas lybicus and Raphicerus sp. and Miotragocerus cyrenaicus); the Homonoids (Sahelanthropus cf. tchadensis); Hippopotamus (Hexaprotodon sahabiensis); Three-toed horse (Cremohipparion sp.); in addition to the birds Eagle (Accipitricidae sp.) and Darter (Anhinga sp.). Meanwhile, the flora are represented by Bushwillow tree (Combretum sp.), Cape ash tree (Ekebergia acpensis), Acacia tree (Acacia sp.), and chestnut tree (Sterculia setigera), and Susage tree (Kigelia africana) (Table 1 and Fig. 7E) as largely understood from the fossil wood Boaz (2009).

6. Arid Desert-like paleo-habitat: It was suggested due to the presence of the Rodents Gerbil (Abodabia yardangi); Ground squirrel (Atlantoxerus getulus). Meanwhile, the flora maily represented by Poplar tree (Populus euphraticus) (Fig. 7F) Boaz (2009). 


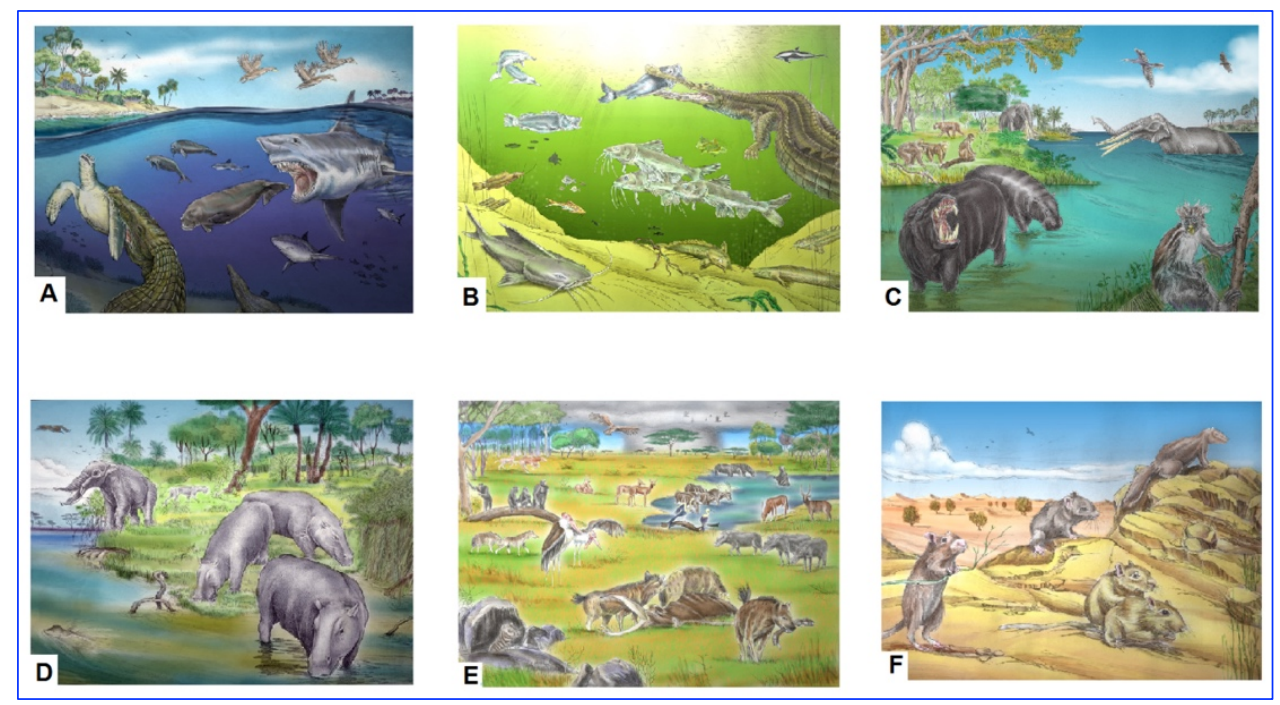

Fig. 7: Hypothetical prevailed paleo-habitats in the As Sahabi area as suggested by Boaz, (2009) Reconstructed by artist Antonio Varelas. (A) Salt wtaer; (B) Eo Sahabi River; (C) Riverine forest and river edge; (D) Water's edge and Eo-Sahabi estuary; (E) Savana; (F) Arid, Desert-like

\section{PRESENT-DAY FAUNA AND FLORA IN AS SAHABI AREA}

The only habitat which is predominating the As Sahabi area today by comparison with the paleohabitats of As Sahabi during Pliocene is the Arid Desert-like, due to the presence of present day Gerbiles and the lack of forests (Palm and Acacia tress) and other aqueous organisms. The only present day fauna reported in As Sahabi area are represennted by:

1- Insects: including, Deathstalker Scorpion (Leiurus quinquestriatus) (Fig. 8A).; Mammals: including, Camels (Fig. 8B), Gerbils and Fennecs (Vulpes sp.).

2- Reptiles: including, Lizards (Fig. 8C).

3- Red beetle insect (Fig. 8D) and desert Ant.

4- Mollusks: including land snails Helix sp. (Fig. 8D).

However, flora is mainly of arid desert plants which are mainly restricted to few annular plants and grasses which strictly growing after short time rainfall in wadis and baltas (Fig. 9A-F), the illustrated flora is not classified herein.

\section{CONCLUSIONS}

The following are the main conclusions:

1- Highlight the Eo-Sahabi river with attention to its possible source and its role in creating the six recognized habitats in Pliocene Sahabi Formation of As-Sahabi area.

2- Compare the documented vertebrate fossils remains during the Pliocene time in reconstructing the prevailed habitats in As Sahabi area. 


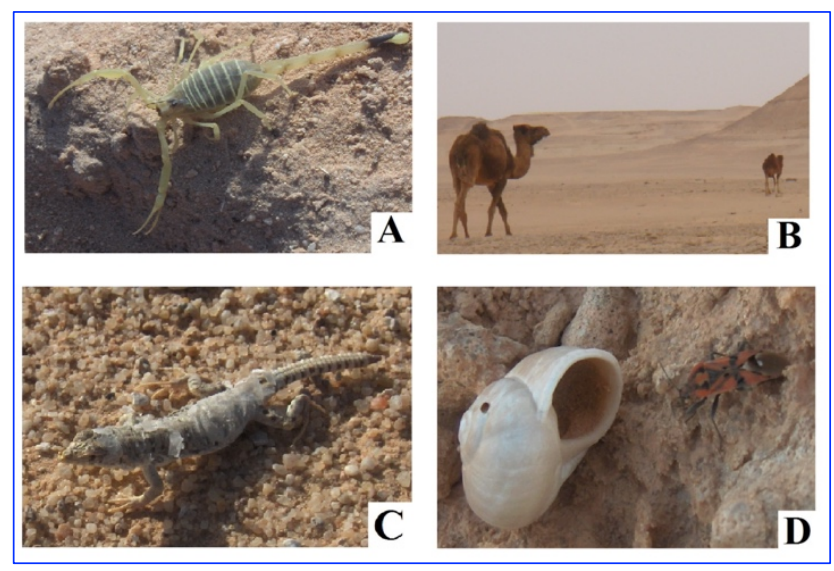

Fig. 8: Desert animals from As Sahabi area, Sirt Basin, Libya (A) Scorpion deathstalker (Leiurus quinquestriatus); (B) Camels; (C) Lizard; (D) Helix and red beetle insect.

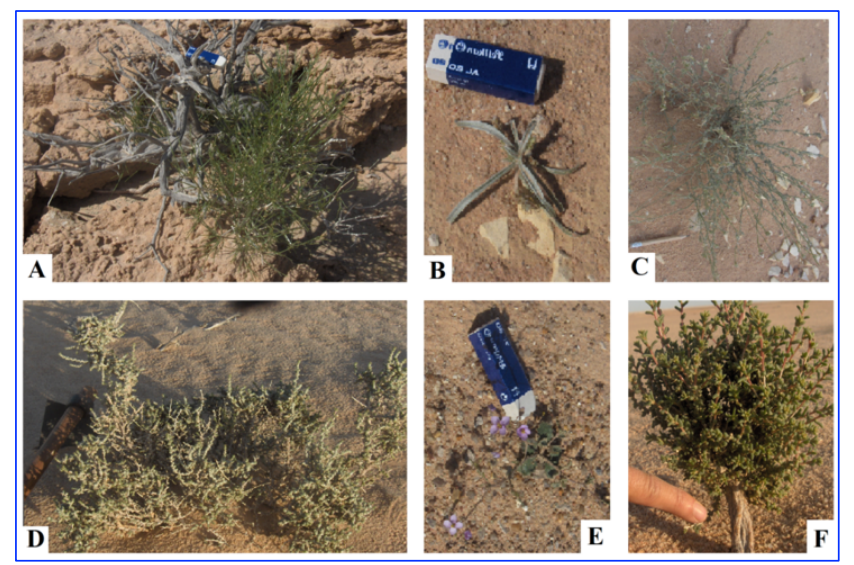

Fig. 9: Desert shrubs from As Sahabi area, Sirt Basin, Libya (A-F not identified)

\section{RECOMMENDATION}

1- The As Sahabi area is highly recommended to be registered as an international natural heritage site in order to conserve the hidden and the exposed vertebrate fossil remains.

2- Protecting vertebrate remains and fossil wood from taking them for any reason.

\section{ACKNOWLEDGEMENTS}

I would like to express my thorough appreciation to all members of East Libya Neogene Research Project, Prof. N. Boaz, Prof. P. Pavlakis, Dr. D. Michailidis, Dr. E. Pavlakis and Dr. M. Shawaihdi) for their company and valuable discussions during the conducted several field seasons (2007-2010) of the East Libya Neogene Research Project. 


\section{REFERENCES}

Barr, F.T., and Walker, B.R., 1973. Late Tertiary channel system in northern Libya and its implication on Mediterranean Sea level changes. In: Ryan, W.B.F., Hsü, K.J. (Eds.), Initial Report Deep Sea Drilling Project, Leg 13, pp. 1244-1251.

Boaz, N.T., 2008. A View to the South: Eo-Sahabi Palaeoenvironments Compared and Implications for Hominid Origins in Neogene North Africa. In: Boaz, N.T., El-Arnauti, A., Pavlakis, P., Salem, M. (Eds.), Circum-Mediterranean Geology and Biotic Evolution During the Neogene Period: The Perspective from Libya. Garyounis Scientific Bulletin, 5: 291-308 (special issue).

Boaz, N. T. 2009. Libya before the Sahara: The vanished world of the Eo-Sahabi Valley. IIHER Occasional Papers 1-12.

Boaz, N.T., El-Arnauti, A., Pavlakis, P., and Salem, M.J. (Eds.) 2008. Circum-Mediterranean Geology and Biotic Evolution During the Neogene Period: The perspective from Libya. Benghazi, Libya: Garyounis Scientific Bulletin, Spec. Issue 5. Garyounis University, Benghazi.

Burckle, L., 1982. Diatoms in coprolites from the Upper Neogene of Sahabi, Libya. Garyounis Scientific Bulletin 4, 1314 (special issue).

Carmignani, L., Salvini, R., and Bonciani, F., 2009. Did the Nile River flow to the Gulf of Sirt during the late Miocene? Bollettino della Societa Geologica Italiana $218: 403-408$.

De Heinzelin, J., and El-Arnauti, A., 1983. Geology of the Sahabi area with a geological map at scale 1:25000. Research Centre Garyounis University, Benghazi, Libya. (Edited by the Section of Cartography and Photo-Interpretation of the Royal Museum for Central Africa, Tervuren, Belgium) in commission of the Research Centre, Garyounis Uinversity, Benghazi, Libya, 59 p.

De Heinzelin, J., and El-Arnauti, A., 1987. The Sahabi Formation and related deposits. In: Boaz, N.T., El-Arnauti, A., Gaziry, A.W., de Heinzelin, J., Boaz, D.D. (Eds.), Neogene Paleontology and Geology of Sahabi. Liss, New York, 1-21.

Deschamps, R., 1987a. Xylotomy of fossil wood from the Sahabi Formation. In: Boaz, N.T., El-Arnauti, A., Gaziry, A.W., de Heinzelin, J., Boaz, D.D. (Eds.), Neogene Paleontology and Geology of Sahabi. Liss, New York, pp. $37-41$.

Deschamps, R., 1987b. preliminary results of the study of fossil wood from the Sahabi, Libya. Garyounis Sci. Bull., Spec. Issue 4: 15-18.

Deschamps, R. and Maes, F., 1987. Paleoclimatic Interpretation of fossil wood from the Sahabi Formation. In: Neogene Paleontology and Geology of Sahabi. Alan R. Liss, New York: 43-81.

Desio, A. 1935. Appunti geologici sui dintorni di Sahabi (Sirtica). Rend. R. Ist. Lett., Ser. 2, 68 (I-V): 137-144.

El-Shawaihdi M. H., Muftah, A. M., Mozley, P. S., and Boaz, N. T. (2014). New age constraints for Neogene sediments of the Sahabi area, Libya (Sirt Basin) using strontium isotope (87Sr/86Sr) geochronology and calcareous nannofossils. Journal of African Earth Sciences 89: 42-49.

El-Shawaihdi, M.H., Mozley, P.S., Boaz, N.T., Salloum F., Pavlakis P., Muftah, A., Triantaphyllou, M. 2016. Stratigraphy of the Neogene Sahabi Units in the Sirt Basin, northeast, Libya, Journal of African Earth Sciences, 118: 87-106

Muftah, A.M., 2013. Biostratigraphic and Temporal Relations between the Neogene Sahabi and Marada Formations, Libya. Contribution to the Age Determination of Their Contained Mammalian Paleofaunas. Unpublished PhD thesis. University of Athens, Greece.

Muftah, A.M., Salloum, F., El-Shawaihdi, M.H., and Al-Faitourim, M.S., 2008. A contribution to the Stratigraphy of Formations of the As Sahabi Area, Sirt Basin, Libya. In: Boaz, N.T., El- Arnauti, A., Pavlakis, P., Salem, M.J. (Eds.), Circum Mediterranean Geology and Biotic Evolution during the Neogene Period: The Perspective from Libya, Garyounis Scientific Bulletin 5: 33-45 (special issue).

Muftah, A. M., Pavlakis, P., Godelitsas, A., Gamaletsos, P., and Boaz, N., 2013. Paleogeography of the Eosahabi River in Libya: New Insights into the Mineralogy, Geochemistry and Paleontology of Member U1 of the Sahabi Formation, Northeastern Libya. Journal of African Earth Sciences, 78: 86-96.

Nicolai, C., 2008. Tracing the As Sahabi channel system in the Ajdabiya Trough, Central Sirt Basin. In: Boaz, N.T., A. El-Arnauti, P. Pavlakis, and M. Salem (eds.), Circum-Mediterranean Geology and Biotic Evolution During the Neogene Period: The Perspective from Libya. Garyounis Scientific Bulletin, Spec. Iss. 5:85-94. 
Paillou, P., Schuster, M., Tooth, S., Farr, S., Rosenqvist, A., Lopez, S., and Malezieux, J.-M., 2009. Mapping of a major paleodrainage system in eastern Libya using orbital imaging radar: the Kufrah River. Earth and Planetary Science Letters 277: 327-333.

Petrocchi, C., 1934. Iritrovamenti faunistici di Es-Sahabi. Riv. Delle Colonie, 3: 773-363, Tripoli.

Petrocchi, C., 1936. Relazione sui ritrovamenti di es-Sahabi. Atti. Del second Congresso di Studi Coloniali (Naples, 1934) 3: 238-246.

Petrocchi, C., 1941. Il giacimento fossilifero di Sahabi. Boll. Soc. Geol. Ital., 40 (1): 107-114.

Rook, L., 2008. The Discovery of the As Sahabi Site: Ardito Desio or Carlo Petrocchi? In: Boaz, N. T., El-Arnauti, A., Pavlakis, P., and Salem, M. J. (Eds.). Circum-Mediterranean Geology and Biotic Evolution During the Neogene Period: The perspective from Libya. Benghazi, Libya: Garyounis Scientific Bulletin, Spec. Issue 5. Garyounis University, Benghazi. 